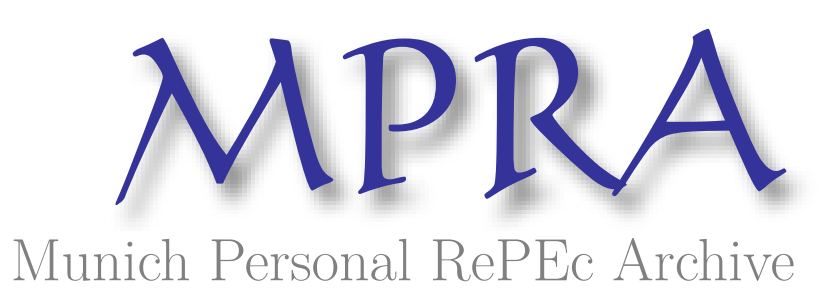

\title{
Sidgwick's Theory of International Values
}

Melitz, Jacques

Tulane University

1963

Online at https://mpra.ub.uni-muenchen.de/84891/

MPRA Paper No. 84891, posted 09 May 2018 14:51 UTC 


\title{
Sidgwick's Theory of International Values ${ }^{1}$
}

\author{
J. Melitz \\ The Economic Journal, Vol. 73, No. 291 (Sep., 1963), pp. 431-441
}

SUMMARY: Henry Sidgwick (1838-1900) is generally believed to have rejected the classical theory of comparative costs. He supposedly maintained, contrary to the classical view, that transportation costs instead of international factor immobilities were the primary basis for a special theory of international values. It is argued in this article that Sidgwick did not contest the classical theory of international values. He merely opposed John Stuart Mill's case for introducing the "equation of reciprocal demand" in international trade theory. Whereas Mill believed that the use of the "equation" was required by international factor immobilities, Sidgwick attributed the need for it mainly to transportation costs.

\section{INTRODUCTION}

HENRY SIDGWICK (1838-1900) is generally believed to have rejected the classical theory of comparative costs. He supposedly maintained, contrary to the classical view, that transportation costs instead of international factor immobilities were the primary basis for a special theory of international values. ${ }^{2}$ It is argued in this article that Sidgwick did not contest the classical theory of international values. He merely opposed John Stuart Mill's case for introducing the "equation of reciprocal demand" in international trade theory. ${ }^{3}$ Whereas Mill believed that the use of the "equation" was required by international factor immobilities, Sidgwick attributed the need for it mainly to transportation costs. However, beyond questioning Mill's analysis of the grounds for a distinct principle of international values, Sidgwick made little attempt to revise the classical theory of international trade, and presented a fairly orthodox treatment of the general subject of foreign trade.

This paper will begin with a summary of the historical development of the currently prevalent interpretation of Sidgwick's theory. Next, an alternative interpretation will be offered, followed by an examination of the rationale for Sidgwick's stand. After a consideration of secondary factors bearing on the issue of interpretation, the paper will close with a brief evaluation of Sidgwick's theory, as newly rendered.

\footnotetext{
${ }^{1}$ I would like to state my indebtedness to John $\mathrm{H}$. Auten for valuable comments, and also to Edgar 0 . Edwards and Walter G. Mellon.

2 Henry Sidgwick (1901). The relevant chapter, "Theory of International Values" (Book II, No. III), stands considerably revised in the two later (and nearly equivalent) editions (1887 and 1901) from its initial state in the first edition (1883). Pertinent changes in editions will be indicated in context.

3 J. S. Mill (1909), Book III, Chapters XVII and XVIII.
} 


\section{DEVELOPMENT OF THE CURRENT INTERPRETATION OF SIDGWICK'S THEORY}

The current interpretation was initiated by Charles Francis Bastable in a little-known article of 1886 titled "Economic Notes." Bastable's view first received prominent attention upon its appearance in his Theory of International Trade with some of its Applications to Economic Policy, published the following year. ${ }^{4} \mathrm{He}$ contended that Sidgwick had treated transportation costs as the only determinant of international values, and criticised Sidgwick severely for this error. Shortly thereafter, Francis Y. Edgeworth defended Sidgwick, saying:

"The new theory of international values which Professor Sidgwick has propounded in his Principles of Political Economy appears to be tenable upon an assumption which, with respect to modern trade, is plausible, namely, that the difference in ' the aggregate of utilities obtainable by similar sacrifices in different localities ' . . . is not much greater than might be accounted for by the cost of transport. If we assume that any greater difference in the level of advantage would be annihilated by a flow of population ... Professor Sidgwick rightly considers that ' an essential part of the reason why a special theoretic treatment has to be applied to the products of international trade is that a double cost of carriage has here to be taken into account. ${ }^{5}$

This defence implied concurrence with Bastable's opinion that Sidgwick had regarded transportation costs as the central determinant of international values. Short of an adherence to this view, Edgeworth would have had no basis for considering the approximate equality of transportation costs and international differences in real costs as a possible vindication of Sidgwick's stand.

Edgeworth's defence was not very effective, having based Sidgwick's theory on a highly debatable empirical assumption. Nevertheless, in 1926 James W. Angell presented the defence as an integral part of Sidgwick's position, making few changes in wording and no reference to Edgeworth. Angell's rendition represents the most complete statement of the current interpretation of Sidgwick, and may therefore be quoted:

"He [Sidgwick] declared that the peculiarity of the determination of international values rests not on the imperfect mobility of labour, but on the fact of distance, which renders international trade costly. He finds that the difference in the aggregates of utility obtainable by similar sacrifices in different localities is not much greater than can be accounted for by the cost of transportation between them. Any substantially greater difference will be annihilated by corresponding movements of the population. The problem therefore lies in the determination of the conditions governing the division of costs of transportation."6

Thereafter, Jacob Viner also argued:

"Sidgwick claimed, however, that it was the existence of transportation costs which alone provided a basis for differentiating the theory of international values from the

\footnotetext{
${ }^{4}$ C. F. Bastable (1886) and (1887), pp. 12-13, 174 (1897 edition, pp. 12-13, 179-80).

${ }^{5}$ F. Y. Edgeworth (1894).

6 J. W. Angell (1926), p. 98.
} 
theory of domestic values." 7

Viner, more so than Edgeworth, of whom the same might be said, manifested considerable uncertainty about Sidgwick's exact meaning. However, no similar uncertainty was displayed henceforth. One authority after another - Chi-yuen Wu, Frank D. Graham, Joseph A. Schumpeter - went on to cite Sidgwick as having put forth a radically new theory of international values and having thrown aside that of "comparative cost." There is hardly a major figure in the field of international trade in this century who has not become party to this interpretation in one way or another. The result is that presently Bastable's view has assumed the status of fact. ${ }^{8}$

\section{NEW INTERPRETATION OF SIDGWICK'S THEORY}

It can be argued, however, that Sidgwick concentrated almost exclusively on the justification for Mill's contention that a special theoretical principle applied to foreign as opposed to domestic trade. Mill had maintained that, with few exceptions, the principle of "cost of production" determined domestic values, while the "equation of reciprocal demand" governed international prices." Sidgwick accepted the assertion of the special significance of the "equation" in international trade theory, but questioned Mill's basis for the belief. Sidgwick's argument can be divided into two parts:

I. Contrary to Mill, international factor immobilities do not explain the need for the "equation of reciprocal demand" in international trade theory.

II. The "equation" is required mainly because of transportation costs.

\footnotetext{
${ }^{7}$ Jacob Viner (1932), p. 375. In the same article Viner also took the considerable trouble of showing that even "if we accept Edgeworth's version of Sidgwick's argument," it does not follow " on the assumption of returns per unit of effort not deviating as between countries by more than the cost of transportation, that relative prices of commodities produced in different countries could not deviate from their relative costs by more than the cost of transport " (idem). See also Viner (1937), p. 470, fn. 4.

8 Chi-yuen Wu (1939), pp. 176-8; Frank D. Graham (1948), pp. 144-5; and Joseph A. Schumpeter (1954), pp. 605-6 and fn. 4. Two other examples of the same interpretation may be found in Joseph Rambaud (1902), p. 379; and Alfred Marshall (1923), pp. 328-9, fn. 1. Marshall had already remarked to Edgeworth in a letter dated August 28, 1902: "Re Sidgwick's theory of cost of transport, I have not decided whether to make any reference to it in my new volume. My view is that he got quite off the rails [the pun, I trust, was unintended] and that it is hardly necessary to say so." Arthur Cecile Pigou (1925, ed., Memorials of Alfred Marshall, p. 435). Luigi Cossa (1899), p. 369, found Henry Sidgwick's chapter on international values "obscure"; Ashley (1909), p. 996, noted that it contained an attempt at original theory; and Schumpeter (1954), p. 127, saw in it an "original but not altogether successful" attempt to improve the theory of international trade in 1912. The chapter has received favourable comments as well. See [Unsigned] (1883), p.46; Rambaud (1902), p. 379; Graham (1948), p. 69, fn. 9; and Bertil Ohlin (1933), p. 141. The only previous account of Sidgwick's theory in reasonable agreement with my view is that of John Neville Keynes (1926).

9 Sidgwick also attributed to Mill the position that the principle of determination of value by "cost of production" was entirely inapplicable to international trade. This was uncharacteristically unfair of Sidgwick. Whatever Mill may have said in some unguarded moments - of which there were some (see Mill (1909, pp. 574,584 ) - it is patently clear that he regarded "cost of production" as setting limits to the range of indeterminacy in international prices (see ibid., pp. 576-8, 587). Thus, Mill recognised the relevance of the principle of "cost of production" in international trade theory.
} 
Turning to Part I, Sidgwick held that, in the absence of transportation costs, the existence of a commonly produced good among the trading countries would dispense with the need for the "equation of reciprocal demand" even if international factor immobilities were present. Abstracting from transportation costs, and supposing a commonly produced good, the principles of price determination applicable to domestic trade would determine international values as well. To quote Sidgwick:

"Take Mill's illustration: suppose England imports wine from Spain, giving cloth in exchange.... Suppose that there is at least one other commodity-say corn-which is produced both in England and in Spain. According to Mill's general theory of value, discussed in the preceding chapter, the relative values of cloth and corn in England must be determined by their comparative costs of production; and, again, the relative values of wine and corn in Spain must be determined in the same way. But if we suppose cost of carriage to be eliminated, there is no reason why the value either of wine or cloth should be altered by exportation; hence, the values of both wine and cloth relatively to corn, and therefore relatively to each other, must be as much determined by cost of production as the values of home commodities are."10

The closing portion of this quotation, which states that under the stipulated conditions the relative value of English cloth and Spanish wine would be "as much determined by cost of production as the values of home commodities are," was a revision of the earlier statement in the first edition:

"The values of both wine and cloth relatively to corn, and therefore relatively to each other, must be completely determined by the principle of cost of production.... "11

This strongly suggests that the later wording was intended to be read as saying that the international values of cloth and wine would be determined by the same principles as those which ruled domestic values and not necessarily exclusively by "cost of production." A sentence only a few lines further on in the later editions adds heavy support to such a reading:

"As we have seen in the preceding chapter, the cost of production of all the commodities concerned [i.e., corn, wine, and cloth] will, generally speaking, tend to be somewhat modified by changes in the demand for them...."

The view that domestic values were generally determined both by "cost of production" and demand was, in fact, the dominant theme of the previous chapter on the "Theory of Exchange Value of Material Products" (in all three editions of the Principles). Thus, Sidgwick's argument may best be regarded as follows: given a commonly produced good, then in the absence of transportation costs, international values would be determined strictly by "cost of production" and demand, and independently of the "equation of reciprocal demand." The important implicit distinction between the

10 Sidgwick (1901), pp. 212-14.

11 lbid., 1883 edition, p. 218. 
"equation of reciprocal demand" and the principle of "demand" will be clarified in the following section of this paper. ${ }^{12}$

Sidgwick appended a very disturbing footnote to the last statement in the foregoing quotation from the last edition containing the reference to Mill's illustration. The handling of this footnote has constituted a major problem in the interpretation of Sidgwick's theory:

"It does not of course follow that the wine and cloth will exchange for each other in proportion to their respective costs; since, if (as Mill supposes) labour and capital are imperfectly mobile, the cost of producing corn may be different in the two countries." 13

There are three possible construals of the footnote: two clearly attribute false reasoning to Sidgwick, by virtue of inconsistency if nothing else; and the third, which carries most conviction, allegedly involves an acceptance of Mill's position.

In the first instance the footnote can be understood to mean that wine and cloth would not exchange in (inverse) proportion to their respective money costs of production given a difference between the real costs of producing corn in the two countries. But then the statement obviously would be false and almost impossible to reconcile with the

\footnotetext{
12 Bastable (1887), p. 175, observed, in reply to Sidgwick, that Mill had supposed the immobility of factors to preclude the presence of a commonly produced good among the trading countries (1897 edition, pp. 180-1). (Mill's view rested upon the notion that under factor immobility, differences in geographical factor endowment would cause every good to be produced by one particular country, that country alone having a "comparative advantage" in its production.) However, in the only explicit reference to a critic in the Principles, Sidgwick rejoined in the second (1887) edition that, even supposing factor immobility, a commonly produced good could exist if one of two conditions held true. The first was the presence of more than two countries, in which case any two countries might produce the same good for export to a third. The other was production under conditions of increasing costs. Sidgwick (1901), p. 213, fn. 1. Bastable subsequently maintained that the first of these two arguments was wrong, since one country might underbid the other in their mutual attempt to sell a homogeneous good to a third country. Bastable (1889). He did not challenge the second argument, having previously put forth the same viewpoint himself. According to Bastable (1887), p. 175, however, the argument was incompatible with Sidgwick's thesis, since, if the operation of the law of diminishing returns were admitted, then commonly produced good or not, demand would be a determinant of international values. Bastable (1897 edition, pp. 180-1). As the previous discussion shows, this last counter was invalid. Sidgwick contended that a commonly produced good, together with zero transportation costs, would dispose of the necessity to use the "equation of reciprocal demand," not the necessity to take some account of demand factors. To mention an incidental but interesting point, some years earlier H. K. E. Mangoldt had presented a sophisticated argument establishing the possibility of a commonly produced good under strong conditions. He had assumed both constant real costs and non-coincidence of individual national costs. Edgeworth only succeeded in converting Bastable to Mangoldt's argument after initial difficulty. See Edgeworth (1894), pp. 29-30, 53-5 of the 1925 reprint; Bastable (1887), pp. 181-2 of the 1997 edition; and Edgeworth (1897). Edgeworth then tried to credit Sidgwick with Mangoldt's insight. But it is difficult to acquiesce in Edgeworth's attempt, since Sidgwick's reply to Bastable clearly indicated a more naive conception than that of Mangoldt.

${ }_{13}$ This footnote was absent in the first edition of the Principles, but a corresponding assertion appeared in the main text, adjoining a passage which already has been quoted:

"Hence, the values of both wine and cloth relatively to corn, and therefore relatively to each other, must be completely determined by the principle of cost of production; although the wine and cloth may not exchange for each other in proportion to their respective costs."
} 
associated text. Second, the footnote can be construed as saying that wine and cloth would not exchange in (inverse) proportion to their respective money costs of production given a difference between the money costs of producing corn in the two countries. This assertion would be valid. In this case, however, the footnote would also imply that factor immobilities could explain a difference between the money costs of producing corn in England and Spain. This implication would be contrary to Sidgwick's argument elsewhere in the chapter and difficult to reconcile with classical or modern economic theory. The third interpretation, accepted by Edgeworth, ${ }^{14}$ is that cloth and wine would not exchange in (inverse) proportion to their respective real costs if the real costs of producing corn differed in England and Spain. On the basis of this view, the footnote was an ordinary application of classical economic theory. However, Edgeworth, Marshall and Viner - the only writers on the subject - all maintain that this interpretation signifies a complete retreat to Mill's position. In Viner's words:

"If Sidgwick is conceding that the prices of wine and cloth will not be proportional to their real costs of production, he is accepting Mill's entire case."15

Were this contention correct, the third interpretation, as well as the first two, would render the footnote inconsistent with the text. However, if the contention can be disputed this interpretation may be sustained undermining the clarity or coherence of Sidgwick's position.

The view of Edgeworth, Marshall and Viner is founded on the assumption that Sidgwick attached the same meaning to the "principle of cost of production" as Mill, namely, that goods will exchange in the inverse ratio of their respective real costs. According to Mill's usage, any recognition that factor immobilities might cause goods to exchange in some other ratio would be tantamount to a concession that the "principle of cost of production" must be supplemented. However, Sidgwick rejected many of the simplifying assumptions underlying Mill's conclusion that goods tended to exchange domestically in inverse proportion to their respective real costs, and consequently, departed from Mill's definition of the "principle of cost of production." Sidgwick employed the term to refer to the equilibrium condition that money costs equalled money prices. To cite an apposite passage from his chapter on the "Theory of Exchange Value of Material Products":

" To sum up: the Ricardian theory of the determination of Value by Cost of Production appears to me incontrovertible, at least as applied to modern civilised communities, if it is understood in a broad and vague sense; i.e., if it is understood merely to affirm that industrial competition is a force constantly acting in the direction of equalising the remunerations of producers of the same class in different departments of industry, by increasing the supply - and so lowering the price - of commodities of which the producers are known to be receiving remunerations above the average of their respective classes, and similarly diminishing the supply and raising the price of the products of less profitable industries. But in the more exact and definite form in which

\footnotetext{
${ }^{14}$ Edgeworth (1984), p. 30 of the 1925 reprint.

${ }^{15}$ Viner (1937), p. 489. See also Viner (1932), p. 377; and Marshall (1923), pp. 328-9, fn. 1.
} 
the theory is stated even by Mill, it appears to me open to grave objections."16

And, with even closer bearing on the issue at hand, Sidgwick asserted in his chapter on international values:

"It will be observed that I do not follow Mill in substituting 'labour' for 'wages' as the main element of cost, when treating of international values. I think that the reason before given, for estimating cost of production in terms of remuneration and not of sacrifice, applies to the wares of international trade as much as to any other products." 17

Reading the relevant passages in Sidgwick in the light of his definition of the "principle of cost of production," it becomes clear that the conclusion drawn by Edgeworth, Marshall and Viner was invalid. From Sidgwick's standpoint, the recognition of differences in real costs did not entail the admission that the "principle of cost of production" was inadequate. Theoretically speaking, equilibrium might be determined by money costs, while goods did not exchange in inverse proportion to their respective real costs. Thus, no textual problems arise if Sidgwick's footnote is construed as an acknowledgment that goods may not trade in the inverse ratio of their respective real costs. Given this interpretation of the footnote, Sidgwick held that factor immobilities, while causing real cost differences, did not necessarily lessen the application of the "principle of cost of production" and might not require the introduction of the "equation of reciprocal demand." This position, it may be observed, is largely compatible with classicism. Had Sidgwick emphasised his different definition of the "principle of cost of production "in addition to the possibility of a commonly produced good, he probably would have made himself readily understood."18

As for Part II of Sidgwick's argument, the central importance of transportation costs is manifest in his writing. He constantly abstracted from these costs while attempting to show that factor immobilities were consistent with price determination on the strict basis of the principles applicable to domestic trade. ${ }^{19}$ In fact, he was explicit at several points:

\footnotetext{
${ }^{16}$ Sidgwick (1901), p. 202. See also ibid., p. 185 and the general argument on pp. 192- 205.

17 Ibid., p.218, fn. 1.

18 One important complication is involved in Sidgwick's argument. While denying that international factor immobilities entailed the use of the "equation of reciprocal demand," he granted that without them the "equation" would be unnecessary. He recognised that in the absence of any imperfection whatever in the international mobility of labour and capital, factor movements would dispose of international differences in relative prices independently of the trading of goods:

"If we suppose a perfect mobility of labour and capital within any region, every change in the price of articles brought from a distance to any place in it must be conceived to have an effect proportional to its magnitude in attracting or repelling inhabitants from that place; and in this case the values of wares interchanged between two places within such a region will be determined ultimately not by the equation of reciprocal demand but by the tendency to equalise the aggregate of utilities obtainable by similar sacrifices in different localities" [Sidgwick (1901), p. 217].

19 Note, for example, the qualification "but if we suppose cost of carriage to be eliminated" in the main quotation dealing with the wine-cloth-corn case.
} 
"It would seem then, that if cost of carriage were left out of account there would be no need of a special principle for determining International Values. ${ }^{20}$

"In any case an essential part of the reason, why a special theoretical treatment has to be applied to the products of international trade, is that a double cost of carriage has here to be taken into account." 21

\section{RATIONALE FOR EMPHASIS ON TRANSPORTATION COSTS}

Why did transportation costs necessitate the introduction of a special theoretical principle of price determination? While Sidgwick never focused his attention on this question, a fairly coherent position can be inferred from his text, at least in broad outline.

In Sidgwick's view, transportation costs were inherently "double" costs. That is, the cost of transporting both goods involved in any trade required determination as a single total rather than as a sum of two separate parts. ${ }^{22}$ His apparent reason was some vague notion that all transportation costs arose in the process of exchange, and therefore necessarily related to a carriage of at least two goods. Being "double" in nature, transportation costs gave rise to the problem of "division," or assignment to the trading parties. A number of passages clearly indicate that this problem was fundamental to Sidgwick's emphasis on the theoretical significance of these costs. His main point could not have been that the "division" required some cognisance of demand, since, as noted previously, he recognised demand as a leading determinant of domestic values. Evidently Sidgwick believed that transportation costs acquired special theoretical significance because they entailed consideration, not of demand as such, but of two separate and unaggregated demand curves. This would mean that Sidgwick regarded the distinguishing characteristic of the "equation of reciprocal demand" as its concern with two separate demand curves. The leading evidence may be set forth:

"In fact, ['in the case of the products of international trade'] we have a special case of the kind discussed at the close of the preceding chapter, in which the values of two commodities are causally connected through their being the joint products of one process of production; the one process here being the process of double carriage, each half of which is commercially inseparable from the other." 23

"As we have seen in the preceding chapter, the costs of production of all the commodities concerned [wine, cloth, and corn] will, generally speaking, tend to be somewhat modified by changes in the demand for them: but this consideration is not in itself a reason for special treatment of international values; since, under the circumstances supposed [i.e., the absence of costs of carriage], the demands of the two different countries for each commodity might be treated as one aggregate

\footnotetext{
20 Ibid., p. 214.

21 Ibid., p. 217.

22 He was explicitly concerned with the cost of carrying money, as well as other goods.

${ }^{23}$ Sidgwick (1901), p.217.
} 
demand."24

\section{ADDITIONAL EVIDENCE RELATING TO THE ISSUE OF INTERPRETATION}

As additional support for the new interpretation, it may be noted that Sidgwick's scattered comments regarding practical conditions in international trade agree with the classical stand. He ascribed considerable empirical importance to international factor immobilities. Thus, he maintained:

"No doubt the varying degrees of mobility of labour and capital will have important effects on the course of international trade; since - as we have seen - if wages and interest are considerably higher in one country than in another it may be profitable for the former to import commodities which it could produce with less labour and capital at home." 25

Moreover, as opposed to the currently accepted interpretation of Sidgwick's theory he did not exaggerate the practical significance of transportation costs. He presented the moderate belief that "the proportion of the labour and capital of mankind ... employed in the business of moving goods" was steadily growing." ${ }^{26} \mathrm{He}$ also adopted the mild stand that transportation costs played a greater role in international than in domestic trade. This was the full extent of his emphasis on the practical magnitude of these costs.

Furthermore, Sidgwick deliberately upset Mill's traditional sequence by presenting his chapter on international values immediately after the one on domestic values. Mill had interposed the theory of money between the subjects of domestic and foreign values. Sidgwick's different organization fully accords with my interpretation, which maintains that his discussion of international values was essentially a supplement to the chapter on domestic values, and was not intended as a full treatment of international trade theory.

The only major difficulty confronting the new interpretation is of a purely psychological nature: Why did Sidgwick not reply to the irrelevant remarks of his critics? ${ }^{27} \mathrm{He}$ was not lacking in personal contacts, and could have made himself clear in private, if not through publication.

\footnotetext{
24 Ibid., p.214.

25 Ibid., p.217.

26 Ibid., p.209.

${ }^{27}$ One former objection to Sidgwick's theory remains relevant: namely, Marshall's argument that the factor, distance, operates in domestic as well as foreign trade (loc. cit.). According to this objection, Sidgwick did not provide a basis for a special theory of international trade. Sidgwick himself granted in the later editions of the Principles that his theory was "strictly to be called 'a theory of the values of wares exchanged between distant places,' rather than a theory of international values "[(1901), p. 222]. However, I do not consider Marshall's objection significant, since Sidgwick provided an independent basis for a special theory of international trade. Aside from holding that factor immobilities and transportation costs both partly supported the distinction between internal and external trade, he also cited such factors as governmental interference, national currencies and the special question of national protection (ibid., pp. 223-3). Cf. Walter G. Mellon ( 1959), particularly the reference to Sidgwick on p. 70.
} 
One can speculate, no doubt, that there was little criticism and apparent misunderstanding of his position before 1887, when Bastable's attack first appeared. This might explain Sidgwick's decision to ignore the bulk of Bastable's criticism in the second edition of the Principles. But the same factor would not account for his later silence. The idea that Sidgwick was responsible for a weird new theory of international values clearly was afloat at Cambridge in the 1890s, probably due in great part to the influence of Marshall. ${ }^{28}$ Similarly, Sidgwick's disregard of critics cannot be attributed to his involvement with philosophy and politics. Sidgwick remained reasonably active in economics in the 1890s, attending various meetings of the London Political Economy Club and offering several economic papers. ${ }^{29}$

Of course, it is possible that Sidgwick failed to answer his critics because of doubts concerning his ability to clarify the problem adequately. In any case, I believe that this issue is too conjectural to be assigned considerable weight.

\section{REAPPRAISAL OF SIDGWICK'S THEORY}

Upon reappraisal, Sidgwick's theory continues to appear weak despite several merits. He made a noteworthy, partial attempt to present the classical theory of international values in money terms. Moreover, his emphasis on commonly produced goods, and their role in relating the domestic costs of different countries, strongly anticipated Graham. ${ }^{30}$ He showed, at least for the two-country, two-commodity case, that given a commonly produced good, factor immobilities would not necessitate the use of Mill's formula, the "equation of reciprocal demand," in determining international values. Perhaps his mere concern with the significance of transportation costs in international trade theory should also be regarded as an advance over previous writers. Unfortunately, however, Sidgwick failed to free himself of the notion that the "equation of reciprocal demand," as defined by Mill, was essential in order to determine international values. In addition, he exaggerated the theoretical importance of transportation costs. Under the standard assumptions of general equilibrium analysis, all costs are interrelated.

The main weakness of Sidgwick's chapter may be the leading problem which he chose for contemplation, that is, the grounds for requiring a special principle of international values. Historically, the issue belonged to an earlier period in which "cost of production" was supposed to be the sole determinant of "normal" domestic values in practically all cases. In his own discussion of domestic values Sidgwick discarded the traditional basis for viewing as unique the principle which governed international values. This eliminated any evident reason for entertaining the problem anew. By devoting a whole chapter to Mill's issue, without offering any special justification for such preoccupation, Sidgwick took a reactionary plunge.

\footnotetext{
${ }_{28}$ According to an "Open Letter" by a student to Sidgwick in the Cambridge Review, Vol. II, January 23, 1890, p. 154: "Where you drop, as in the Political Economy, unwarily into a new doctrine of foreign trade, I cannot think your success so great as when .... ."

29 To cite several examples of late economic writing by Sidgwick (1895a, 1895b, and 1899).

${ }^{30}$ Graham (1948), pp. 69-70. Graham does not give Sidgwick adequate credit. Cf. ibid. pp. 144-5.
} 


\section{REFERENCES CITED}

Angell, James W. (1926). The Theory of International Prices, History, Criticism, and Restatement (Cambridge, Mass.).

Ashley, William J. (1909). "Bibliographic Appendix V" of author's edition of Mill, Principles of Political Economy (London).

Bastable, Charles F. (1886). "Economic Notes," Hermathena, Vol. VI, 102 (a University of Dublin publication).

Bastable, Charles F. (1887). Theory of International Trade with some of its Applications to Economic Policy (Dublin), 1st edition; 2d edition, 1897.

Bastable, Charles F. (1889). "Economic Notes," Hermathena, Vol. VII, 120-1.

Cossa, Luigi (1899). Histoire des Doctrines Economiques (Paris).

Edgeworth, Francis Y. (1984). "Theory of International Values," Economic Journal, Vol. IV, in three parts (March, September, December), 35-50, 424-43, 606-38 respectively; reprinted in Papers Relating to Political Economy (London, 1925), Vol. II, as "The Pure Theory of International Values."

Edgeworth, Francis Y. (1897). "Review of Bastable's The Theory of International Trade with some of its Applications to Economic Policy, 2nd ed.," Economic Journal, Vol. VII (September 1897), 398-400.

Graham, Frank (1948). The Theory of International Values (Princeton).

Keynes, John Neville (1926). "Sidgwick, Henry," in Henry Higgs, ed., Palgrave's Dictionary of Political Economy, Vol. III, 759.

Marshall, Alfred (1923). Money, Credit, and Commerce (London).

Mellon, Walter G. (1959). "On the Treatment of Distance in International Trade Theory," Zeitschrift für Nationalokonomie, Vol. XXX (January), 66-85,

Mill, John Stuart (1909) Principles of Political Economy with some of their Applications to Social Philosophy, William J. Ashley, ed. (London); first edition 1848.

Ohlin, Bertil (1933). Interregional and International Trade (Cambridge).

Pigou, Arthur C. (1925). Memorials of Alfred Marshall (London, 1925).

Rambaud, Joseph (1902). Histoire des Doctrines Économiques (Paris).

Schumpeter, Joseph (1954a). Economic Doctrine and Method, R. Aris trans. (London, 1954); 1st edition 1912.

Schumpeter, Joseph A. (1954b). History of Economic Analysis (New York). 
Sidgwick, Henry (1895a). "The Economic Lessons of Socialism," Economic Journal, Vol. $\mathrm{V}$, September, 336-46; reprinted in Miscellaneous Essays and Addresses (London, 1904), 235-48.

Sidgwick, Henry (1895b). "Letter to the editor," Economic Journal, Vol. V (September), 411-12.

Sidgwick, Henry (1896). "Note on the Memorandum of Sir R. Giffen to the Royal Commission on the Financial Relations between Great Britain and Ireland," Minutes of Evidence, March 29, 1895, in Report, Commissioners, Vol. XXXIII, 180-3.

Sidgwick, Henry (1899). "Answers" in " Memoranda Chiefly Relating to the Classification and Incidence of Imperial and Local Taxes," issued by the Royal Commission on Local Taxation, Report, Commissioners, Vol. XXVI, [c. 9528], 99-112.

Sidgwick, Henry (1901). Principles of Political Economy (London, third and last edition; first edition, 1883; second edition; 1887.

Unsigned (1883). "The Principles of Political Economy," Cambridge Review, Vol. V, (October 31).

Viner, Jacob (1932). "The Doctrine of Comparative Costs," Weltwirtschaftliches Archiv, Vol. 36, 356-414.

Viner, Jacob (1937). Studies in the Theory of International Trade (New York).

Wu, Chi-yuen (1939). An Outline of International Price Theories (London). 